\title{
The "refugee crisis" as an opportunity structure for right-wing populist social movements: The case of PEGIDA
}

\author{
Marco Bitschnau*, University of Neuchâtel, Swiss Forum for Migration and Population Studies \\ (SFM), Switzerland \\ Dennis Lichtenstein, Austrian Academy of Sciences/Alpen-Adria-University Klagenfurt, Institute \\ for Comparative Media and Communication Studies (CMC), Austria \\ Birte Fähnrich, Berlin-Brandenburg Academy of Sciences, Germany
}

${ }^{*}$ Corresponding author: marco.bitschnau@unine.ch

\begin{abstract}
Current research on right-wing populist communication is often confined to political parties, with social movements receiving much less attention. To help fill this research gap, we examine the frames and master frames of the PEGIDA movement and the role of the 2015 "refugee crisis" in shaping them. Using qualitative content analysis of speeches held at PEGIDA rallies between 2014 and 2016, we identify two distinct master frames, each consisting of five particular frames. Besides an initial master frame about the allegedly looming Islamization of Europe, a second master frame dealing with the Perils of Asylum emerge during the "crisis" - ultimately, both converge, with the latter incorporating central elements of the former. These findings buttress our interpretation of the "crisis" as an opportunity structure that helped right-wing populist social movements to revitalize their message and broaden their audience. However, its long-term impact still appears limited as PEGIDA's influence has greatly waned in recent years.
\end{abstract}

Keywords

PEGIDA, framing, refugee crisis, social movements, content analysis, right-wing populism, Islam

\section{Introduction}

Over the past decade, the rise of right-wing populism, its challenge to representative democracy, and its impact on liberal politics has been frequently discussed among both social scientists and political practitioners (e.g., Bonikowski, Halikiopoulou, Kaufmann, \& Rooduijn, 2019; Norris \& Inglehart, 2019; Wodak, KhosraviNik, \& Mral, 2013). This is all the more true for Germany, where heated discussions about minorities (e.g., after the release of Thilo Sarrazin's Islamophobic bestseller Deutschland schafft sich ab [Germany abolishes itself]), the political fallout of Europe's sovereign debt crisis, and the unmasking of the neo-Nazi terrorist group Nationalsozialistischer Untergrund [National Socialist Underground] had ushered in an era of growing discontent and polarization. In only a couple of years, the country witnessed the rise of its most successful far-right party in over seven decades (i.e., the Alternative für Deutschland [Alternative for Germa$n y], A f D$ ), the popularization of right-wing populist and conspiracist media platforms (e.g., PI-News and Deutschland-Kurier), and the birth of a new social movement: PEGIDA (Patriotische Europäer gegen die Islamisierung des Abendlandes [Patriotic Europeans against the Islamization of the Occident]). Appearing on the political scene in late 2014, this Dresden-based group quickly gained notoriety by staging protest rallies against what its supporters perceived as an accelerated Islamization of country and continent (e.g., Rehberg, Kunz, \& Schlinzig, 2016; Vorländer, Herold, \& Scheller, 2018). Unsurprisingly, this message proved attractive to many on the right, and it did not take long until similar but less successful movements began to emerge in other German cities - LEGIDA in Leipzig, DÜGIDA in Düsseldorf, and BÄRGIDA in Berlin, to name but a few. In 
some countries, most notably the United Kingdom, the PEGIDA label even morphed into an eclectic "rallying point appropriated by pre-established radical right activists" (Berntzen \& Weisskircher, 2016, p. 56), who were neither connected to the Dresden group nor did they have the recognition of its leadership.

Most initial research on PEGIDA was sociodemographic and sociopsychological in nature, examining its supporters, their motives, attitudes, and group characteristics (e.g., Daphi et al., 2015; Patzelt \& Klose, 2016; Vorländer et al., 2018). In contrast, a comprehensive exploration of the content of PEGIDA's messages was (and still is) rather limited. As is scholarship on the communication of populist actors, which gives considerably more attention to political parties (e.g., Ernst, Engesser, Büchel, Blassnig, \& Esser, 2017; Hatakka, Niemi, \&Välimäki, 2017; Kalsnes, 2019) than to social movements (but see e.g., Guenther, Ruhrmann, Bischoff, Penzel, \&Weber, 2020; Nissen, 2020). Based on a qualitative content analysis, this article contributes to overcoming these limitations. Inquiring into PEGIDA's framing and the impact of the 2015 "refugee crisis", ${ }^{1}$ it presents new insights into the communication strategies of right-wing populist social movements in times of increased political contestation.

\section{Theoretical foundations}

Due to its demands, PEGIDA is typically classified as such a movement and thus as belonging to the rapidly expanding field of populism studies. Populism, despite having been theorized intensively in recent years, is still a vague concept with a diverse range of possible meanings. According to Gidron and Bonikowski (2013), it can be

1 "Refugee crisis" is potentially misleading because it may be understood as a crisis caused by those fleeing war and persecution, and not by those who are responsible for their plight or failed to provide them with adequate support. Distancing ourselves from this reading of the term, we place it in double quotation marks throughout this article. inter alia understood as ideational (e.g., Mudde, 2004; Mudde \& Rovira Kaltwasser, 2012; Stanley, 2008), performative (e.g., Jagers \& Walgrave, 2007; Moffitt, 2016), or strategic (e.g., Barr, 2009; Weyland, 2001). Although these paradigms entail different methodological implications, they are not necessarily exclusive; rather, their integration into a joint concept of populist political communication has been proposed (Aalberg \& de Vreese, 2017).

Populist communication has been associated with a certain set of stylistic features, most prominently with simplification, dramatization, emotionalization, and invocations of common sense (Mazzoleni, Stewart, \& Horsfield, 2003; Mudde, 2007; Rooduijn, 2014). While the populist message seeks to elicit strong feelings, such as enthusiasm and anger, much of its content involves three distinct elements: (1) people-centrism, (2) anti-elitism, and (3) the identification of an out-group (Aalberg \& de Vreese, 2017; Jagers \& Walgrave, 2007; Kriesi, 2014). People-centrism emphasizes popular sovereignty and unity, while anti-elitism evokes notions of a selfish elite that has become estranged from the people and is therefore incapable of comprehending its true will. Last, to identify an out-group means to designate a collective minoritarian "Other" that, in the populist's imagination, is the direct or indirect beneficiary of the people's misfortune.

Some have argued that these three elements fit the logic of modern mass media and provide populist actors with the "oxygen of publicity" (Aalberg \& de Vreese, 2017 , p. 4) that enables them to spread their message and exercise discursive influence (e.g., Mazzoleni, 2014; Vorländer et al., 2018). These actors can be individual politicians, political parties, and governments but also social movements, which can be defined as heterogeneous networks striving for social or political change (or attempting to resist such change) through orchestrated collective action (Rucht \& Neidhardt, 2001). Because they are conscious of the fact that competing for a resource as scarce as public attention requires enduring popular support, social movements 
often seek to generate a sense of group identity and ethos (McAdam, McCarthy, \& Zald, 1996). A handy tool to reach this goal is the use of social media platforms; Facebook, Twitter, YouTube, and, more recently, TikTok are the most relevant examples in this regard (e.g., Ernst, Esser, Blassnig, \& Engesser, 2019; Priante, Ehrenhard, van den Broek, \& Need, 2018). These platforms allow social movements to gain direct access to dispersed and disproportionately young audiences while bypassing traditional information gatekeepers (e.g., Gaby \& Caren, 2012; Haller \& Holt, 2019; Stier, Posch, Bleier, \& Strohmaier, 2017). As a consequence, many youth-oriented right-wing movements put their focus on connective rather than collective action (Bennett \& Segerberg, 2012) and emphasize the role of digital communication (Bogert \& Fielitz, 2019; Guenther et al., 2020). PEGIDA differs from them insofar as its online activities are less elaborate in style and excessive in scope. Even though Facebook used to be of relevance during the movement's early phase, its main purpose was to address an already sympathetic audience.

To better understand PEGIDA's communication strategy, we studied its frames, which is an established approach in research on collective identities and action (e.g., Benford \& Snow, 2000; Snow, Vliegenthart, \& Ketelaars, 2019). In the social movement context, frames can be defined as bundles of "conscious strategic efforts by groups of people to fashion shared understandings [...] that legitimate and motivate collective action" (McAdam et al., 1996, p. 6) by highlighting selected aspects of an issue and aligning them with key movement demands (Entman, 1993). However, since social movements are, by nature, heterogeneous, they may not rely on such particular frames alone but attempt to create overarching master frames that link their goals to an idealized "Us" (Benford \& Snow, 2000). This strategy is popular among other populist actors as well: As Rooyackers and Verkuyten (2012) noted in the case of Geert Wilders and his Partij voor de Vrijheid, efforts to reframe the public's collective identity and present one's own beliefs as prototypical are essential instruments in the populist toolbox.

Periods of crisis and uncertainty provide highly attractive opportunity structures to foster the creation of master frames. Whenever a crisis arises, it usually entails the disintegration of norms and beliefs that have long been taken for granted in society (Rosenthal, t'Hart, \& Charles, 1989; see also Bitschnau, Ader, Ruedin, \& D'Amato, 2021), which encourages many people to raise their voices and engage in collective action. While this action is often rooted in the ramifications of the crisis on their lives, one must not forget that crises are always subject to social construction and interpretation. Their cause, outcome, magnitude, and teleological dimension are primarily a matter of perception, and depend to a far greater extent on hopes, fears, or ideological predispositions than on factual evidence (Seeger \& Sellnow, 2016; Walby, 2015). Just like other political actors, social movements may attempt to seize the moment and exploit what is perceived as crisis for their own gain: for example, to mobilize supporters and put pressure on the government (della Porta \& Mattoni, 2014; Gamson \& Meyer, 1996) or, in the case of populist social movements, to assign responsibility to elites (Mudde, 2004) while casting themselves as advocates of those who unjustly carry the burden of the crisis.

A look into recent history gives us a more comprehensive understanding of how important crises can be to the success of social movements. One particularly noteworthy example is the catastrophe of Chernobyl in 1986, which not only helped anti-nuclear movements garner mainstream attention (Koopmans \& Duyvendank, 1995) but also paved the way for the anti-nuclear politics of the present. Not as lasting (but nonetheless impactful) was the rise of Occupy Wall Street and similar anti-austerity movements in the wake of the economic, financial, currency, and debt crises of the 2000s and 2010s (e.g., della Porta, 2012; 2015; Gerbaudo, 2017; Langman, 2013). Even more recently, a wave of pro-environmental movements, particularly Fridays for Future and Extinc- 
tion Rebellion, has swept across Europe. Headed by media-savvy activists, they established themselves as relevant stakeholders in a short period of time and have been responsible for numerous policy advances since (e.g., in Germany, their activism and pressure helped pass the 2019 Climate Action Law).

But while the aforementioned movements have been progressive in character and concerned with articulating demands from a distinctively countercultural position, others appeal to more right-leaning audiences; in the case of PEGIDA, to an audience agitated by an event commonly referred to as the "European refugee crisis” (e.g., Lichtenstein, Ritter, \& Fähnrich, 2017; Vorländer et al., 2018) and its aftermath. ${ }^{2}$ During this humanitarian "crisis", several hundred thousand refugees applied for asylum in Europe within only a few months, with the question of their admission and treatment soon turning into a source of perpetual controversy. Even in Germany, the European country most affected by their arrival, the initially warm and welcoming attitude of the public evaporated with time and gave way to increasing skepticism (see Lichtenstein, 2021). ${ }^{3}$ Calls to close borders and tighten asylum policies became common by late 2015, with a notable effect on PEGIDA's discursive relevance. After having been weakened by scandals and unfavorable press coverage in the months prior, the movement once again attracted a great many Spaziergänger [walkers] to its rallies (Kemper, 2015). ${ }^{4}$ Against this background,

2 Chryssochoou (2018) has shown that those who express support for far-right positions in times of crisis are often not challenging the system but disaffected by it. They are "betrayed believers" in search of a new identity that is offered by movements like PEGIDA.

3 This was particularly the case after the 20152016 New Year's Eve assaults in Cologne. Stereotypes about the violent and sexually frustrated Arab "Other" (e.g., Boulila \& Carri, 2017; Weber, 2016) dominated the media coverage, and xenophobic incidents became more frequent.

4 In December 2014 and January 2015, PEGIDA regularly mobilized between 15000 and 25000 protesters but lost most of this sup- we examine the role of the "crisis" in PEGIDA's framing by asking:

1) Which (master) frames can be found during the "refugee crisis"?

2) How do these (master) frames relate to each other against the "crisis" background?

\section{Methodology}

To provide answers to these questions, we analyzed 63 speeches given by 27 speakers at 14 PEGIDA rallies between 2014 and 2016, which we had retrieved from a PEGIDA-affiliated YouTube channel. By uploading and sharing videos of its rallies, PEGIDA deviates from the sophisticated audience targeting strategies of other right-wing populist actors (e.g., Ernst et al., 2019; Guenther et al., 2020; Maly, 2019), which makes it possible to access its speech contents and frames more directly.

Our analysis covers a period that encompasses both PEGIDA's formative stage and the first year of the "crisis." We selected four different series of rallies (i.e., December 2014 to January 2015; July to September 2015; January 2016; June to August 2016) to ensure their balanced distribution over the whole examination period. Each series comprises between two and five recorded rallies, with three to six speeches per rally (not counting announcements and interruptions) and a rally duration ranging from 33 to 141 minutes (93 minutes on average). As a matter of principle, we covered these rallies in their entirety; they usually began with organizational remarks and contained extensive footage of the protest walks. We selected more rallies from the two summer periods because these took place on a bi-weekly rather than weekly basis. As a result, they were longer, less repetitive, and more diverse in terms of content.

port over the following months. Due to the heightened salience of the "refugee crisis", these numbers bounced back to around 20000 by October 2015. 
We first noted the names and number of speakers, length and number of speeches, guest speakers' affiliations, and speech interruptions. Only four out of 27 speakers were members of PEGIDA's core team (i.e., Lutz Bachmann, Siegfried Däbritz, Tatjana Festerling, and Kathrin Oertel), with most being guests (18) or representatives from other GIDAs (5), such as the nearby Leipzig and Chemnitz branches. We then started our analysis by extracting statements (defined as coherent and content-related language segments) from speech transcripts that either referred to the "crisis" or evoked related allusions to an external threat $(\mathrm{N}=418)$.

These statements constituted our data and were coded via the frame elements of problem description, problem cause, problem attribution, and problem intervention proposed by Entman (1993) and later refined by Jecker (2014). We included only statements that contained two or more elements and developed our categories and subcategories inductively. The coding itself was conducted by two of the authors who participated in intensive training to ensure consistently high reliability. Both worked independently from each other but met regularly to compare their results and discuss borderline cases. Following Mayring's (2014) structuring approach, the statements were then condensed and systemized over several iterative steps until the particular frames could be grouped into holistic master frames.

\section{Findings}

Regarding the first question, we find two different master frames that convey PEGIDA's central reference points. The first, Fears of Islamization, relates to the movement's initial message; it contains expressions of cultural anxiety and attempts to establish a dichotomy between a European in-group and a Muslim out-group. The second, Perils of Asylum, emerges during the first months of the "crisis" but soon becomes a similarly prominent leitmotif. It denounces asylum seekers from Africa and the Middle East by portraying them as particularly visible embodiments of "crisis"-related disruption and danger.

\subsection{Fears of Islamization}

The Fears of Islamization master frame consists of five particular frames: Cultural Inferiority, Historical Antagonism, Unwillingness to Integrate, Dangers of Infiltration, and Terrorism and Violence. Each represents another facet of how the Islamic threat is imagined. In Cultural Inferiority, Islam is described as primitive and incompatible with European values and civilization. This line of thought is supplemented by culturalist claims that in Islamic societies, women "possess no worth" (Bachmann, speech held on August 1, 2016), LGBTQ individuals get hanged, and non-believers are subject to humiliating treatment. By associating Islam with bigotry and showing superficial solidarity with those suffering from religious extremism, this frame follows the increasingly popular right-wing populist strategy of cloaking Islamophobia in a more acceptable civilizationist jargon (Brubaker, 2017). The distinction between the in-group and the out-group is first discursively established and then linked to competing concept pairs, such as superior/inferior, civilized / savage, and progressive / regressive.

The second frame, Historical Antagonism, eternalizes this hierarchy by interpreting the antagonism between Christianity, secularism, humanism (the Occident: tolerance and rationality), and Islam (the Orient: relapse into barbarism and superstition) as embedded in a centuries-old conflict between reason and fanaticism. Whenever both worldviews meet, so the argument goes, they will inevitably clash since Islam's lust for power prevents peaceful co-existence. This conception is reinforced by allusions to, and civilizationist reinterpretations of, past conflicts between Christian and Islamic powers. Violent encounters like the Battle of Tours in $732 \mathrm{AD}$, where Frankish knights halted the advance of Umayyad raiders, are in this sense interpreted as direct precur- 
sors to the fight that PEGIDA claims to be forced to wage today. ${ }^{5}$

The next two frames, Unwillingness to Integrate and Dangers of Infiltration, provide contradictory accounts of Islamic life in Europe. The former consists of complaints about the refusal of Muslims to peacefully integrate into European societies. After mid-2015, it gradually evolves into the deterministic conviction that all integration efforts are futile because "these people will never betray their culture" (Bachmann, speech held on August 1,2016$)$. This pessimistic angle is often accompanied by the notion that Muslim archaisms have been imported to Germany en masse, putting natives in serious danger. Prominently referenced are "honor killings, sharia law, clan leaders, Arab street gangs, head kicking, cartoon controversies, burqas, halal slaughtering [...]" (Festerling, speech held on September 7,2015$)$, and other cultural practices deemed disturbing, strange, or harmful.

By stark contrast, Dangers of Infiltration postulates that many Muslims have created the impression of successful integration but only to infiltrate political parties, media channels, schools, and other key institutions and prepare them for an Islamic takeover. Here, Muslims are imagined as natural-born schemers, always waiting for an opportunity to trick naïve "infidels" into believing that they adhere to the tenets of secularism and democracy. And as Germany is "governed by madmen" (Horst, speech held on September 14, $2015)^{6}$ who fail to acknowledge the obvious, these alleged Islamic moles have permeated even the highest echelons of power. In a misinterpretation of Taqiyya, ${ }^{7}$ it is even claimed that Muslims are allowed, if not ordered, to lie and betray as long as

5 Further references include the Battle of Lepanto (1571), the Siege of Vienna (1683), and the Crusades. The latter are interpreted as defensive enterprises aimed at reclaiming Christian lands that were previously taken by an ever-expanding Islam.

6 This speaker's last name is unknown.

7 A historical practice in Shia Islam of concealing one's faith when under threat of persecution or compulsion. it is in the interest of their religion. While bearing resemblance to popular conspiracy theories, such as Renaud Camus' Great Replacement, this fear of the double-faced Islamic infiltrator follows the much older tradition of suspecting a threatening foreign "fifth column" in one's country; a pernicious trope that has been used for centuries to justify the persecution of ethnic and religious minorities.

Finally, evoking the memory of terrorist acts in which Muslims were involved, Terrorism and Violence insinuates the existence of an Islamic master plan to ravage "the West" by fire and sword. According to this frame, violence is considered a virtue in Islam, rooted in the teaching of Muhammad and legitimized by Qur'anic doctrine. Terrorism comes "from the heart of Islam" (Stürzenberger, speech held on August 1, 2016), and whoever denies this must be "blind or paid off" (Däbritz, speech held on July 18, 2016). Different from the other Fears of Islamization frames, Muslims are linked to concrete actions this time, which leads to an infusion of PEGIDA's culturalist discourse with pre-existing post-9 / 11 narratives.

\subsection{Perils of Asylum}

The Perils of Asylum master frame also consists of five particular frames: Asylum Seekers as Economic Burden, Asylum Seekers as Security Threat, Asylum Seekers as Cultural Danger, Asylum Seekers and Political Elites, and Asylum Seekers in the Media. All are varieties of the same sinister theme of political treason and disaster. Asylum Seekers as Economic Burden originates in the basic suspicion that "these people cost us a lot of money" (Wagensveld, speech held on December 8, 2014) and are pampered with state-sponsored amenities (e.g., cell phones and designer clothing). This "generosity" is then rejected as undeserved and contrasted with insufficient funding for schools, hospitals, and other public infrastructure projects. "[Chancellor Merkel,] you allow lazy Africans to plunder our welfare system when they should rebuild their own home countries" (Köhler, speech held on July 13, 2015) is a typical complaint in this regard, relativiz- 
ing the hardships suffered by the "Other" and reproducing colonial narratives of idle Blacks. The populist triad of elite, people, and out-group appears here in particularly graphic terms: The elite betrays the people it has sworn to serve by squandering the fruit of its labor in order to accommodate undeserving out-group members.

This notion of undeservingness is further reinforced in Asylum Seekers as Security Threat, which suspects that many radicals have seized the "crisis" as an opportunity to enter Germany in disguise. Naturally, this is a cause of concern, and speakers such as Lutz Bachmann frequently emphasize that "we can only guess how many of these self-declared Syrians are real Syrians, and how many Islamists, terrorists, and Salafists are among them. I don't even want to think of such a scenario" (Bachmann, speech held on September 7, 2015). In contrast to the Terrorism and Violence frame, this threat does not emanate from an ethno-cultural trait but is the byproduct of political naivety to which the solution could not be more straightforward: "End this solidarity nonsense! And then kick all these cutthroats, terrorists, and dirty Islamists out of Europe!" (Stürzenberger, speech held on August 1,2016 ).

Less concrete is Asylum Seekers as Cultural Danger. This frame pivots on anxieties that the ontological essence of Germanness is jeopardized by asylum-based immigration. The presence of the "Other" is feared for it may change the ethnic face of the nation, threaten the political order, exert demographic pressure, and subvert established norms. Georg Tegetmeyer, a far-right activist affiliated with PEGIDA's Nuremberg branch (Nügida), even invokes the biblical account of the Tower of Babel to illustrate the experience of utter alienation that stems from the impression of being overrun by alien influences: "We walk through cities that have become foreign to us. Do you remember the story of Babylon? We feel the same right now. Many voices, many languages, and we don't understand them; we don't understand anything" (Tegetmeyer, speech held on January 4,2016$)$. As an antidote, it is suggested that there should be greater awareness of Germany's cultural heritage and more respect for majoritarian norms and values.

The remaining frames, Asylum Seekers and Political Elites and Asylum Seekers in the Media, go in a slightly different direction: They do not focus on the refugees but on those responsible for, and supportive of, liberal asylum policies. High-level German politicians (especially Chancellor Merkel) are accused of "inviting" asylum seekers to either replace the electorate or curry favor with industry bosses looking for a pretext to cut the wages of low-skilled natives. Meanwhile, mainstream journalists are attacked for knowing about this plan but keeping silent. Instead of raising their voices in protest, they rejoice "just as they did in 1914 and 1933!" (Wilfried, speech held on July 13, 2015). ${ }^{8}$ In the end, both frames depict the elite as a treasonous camarilla of immigration profiteers.

\subsection{Frame convergence and development}

Regarding the second question, our findings address the link between both master frames. Most importantly, we see that their contents converge over time and the differences between Muslims and refugees become blurred. Refugees are increasingly perceived as Muslims, regardless of their skin color, country of origin, or creed, while Muslims are identified with foreigners and Schutzsuchende [protection seekers]. This culturalization of refugees and simultaneous ethnicization of Muslims becomes particularly visible when PEGIDA speakers argue that “we don't want Muslim refugees [who arrive] holding the Qur'an in their hands, but [we want] persecuted Christians" (Festerling, speech held on July 13, 2015) and that not "one single foreign Muslim should be allowed to enter Europe during the next years. The [...] Islamization and terrorization of the Occident must end!" (Däbritz, speech held on July 18, 2016). By implying that Muslims

8 This speaker's last name is unknown. His statement refers to the uncritical press coverage during the outbreak of World War I ("1914") and the rise of Adolf Hitler ("1933"). 
are by definition non-Europeans, citizens of majoritarian Muslim European countries (e.g., Albania or Kosovo) and converts are $a$ priori excluded from the culturally Christian and spiritually secular Abendland that PEGIDA envisions.

However, this convergence between both master frames appears less as a merger and more as an absorption, with the evermore dominant Perils of Asylum master frame incorporating central elements of the older Fears of Islamization master frame. In other words, PEGIDA's opposition to Islam does not vanish against the backdrop of the "crisis" but becomes part of it, contributing to the "crisis" narrative that something dangerous is happening, something that might spell the end of Germany as an ethnically and culturally homogeneous entity.

Aside from these observations, there are several indications that the rhetoric of PEGIDA speakers grows more vulgar and hostile over time. While there were at least occasional expressions of respect for Muslims in late 2014 (under the strict condition of assimilation), later speakers invent insulting terms, such as "Korandertaler" (a portmanteau of Koran for Qur'an and the Neanderthal species), "Kassyrer" (another portmanteau that fuses kassieren ["to cash in"] with Syrians), or "Sprenggläubige" (["believers in explosions"], a pun on strenggläubig [holding strong religious beliefs] which is frequently used to describe pious Muslims). Other derogatory terms include "Messermänner" (["knife-men"], alluding to the alleged overrepresentation of Muslims in violent crime), "Scheinasylanten" (["sham asylum seekers"], invoking fraud and deception), "Invasoren" (["invaders"], equating human mobility with military action), and "Kulturbereicherer" (["cultural enrichers"], meant in a sarcastic and scornful way).

This tendency toward rhetorical radicalism is complemented by the desire to be considered the center of political resistance, a desire that can be found in both master frames. At its core is the belief that the situation may look grim but is far from hopeless. Too strong is the German warrior spirit that has defeated the enemies of freedom and sovereignty in the past, be they "the Romans in the Teutoburg Forest, the Turks at the gates of Vienna, or even the troops of Napoleon at Leipzig [...]; in the end, we will be victorious!" (Sven, speech held on August 10, 2015). ${ }^{9}$ By making such references, PEGIDA poses as a bona fide national movement and transcends the local context from which it has originally emerged; by having recourse to events such as the Ottoman siege of Vienna, it also transcends this national context and positions itself as part of a civilizationist project aimed at defending a pan-European identity. ${ }^{10}$

\section{Discussion}

Examining right-wing populist communication from a social movement angle, this article analyzed frames and master frames of PEGIDA in terms of how they relate to the "refugee crisis." Our findings suggest the existence of two distinct master frames that consist of several particular frames. One of them - Fears of Islamization - is concerned with PEGIDA's original message, whereas the other - Perils of Asylumaddresses the fallout of the "crisis." Both the appearance of Perils of Asylum and the observation that it incorporates core elements of Fears of Islamization mirror findings by Puschmann, Ausserhofer, \& Šlerka (2020, p. 238), whose investigation of comments posted on PEGIDA's Facebook page show that the "topic Refugees peaks in October 2015, along with asylum applications in Europe," while there is a "relative decline in the topics Islam and the Media."

It also becomes clear that PEGIDA considered the "refugee crisis" as an opportunity structure to revitalize its message and

9 This speaker's last name is unknown.

10 PEGIDA's distinctive Saxonian and Eastern German character is still important. While Western Germany is associated with crime and cultural degeneracy, Eastern Germany appears as the authentic Germany: a place not yet tainted by the "multicultural madness" of Munich, Frankfurt, or Cologne. In this sense, PEGIDA localizes "global developments in a peculiar way" (Bock, 2019, p. 224). 
reinterpret the populist meta-contrast between a homogeneous and positively connotated in-group and a threatening and negatively connotated out-group. Already dominant from the outset, this contrast is reinforced by blending different out-group characteristics (e.g., religion, ethnicity, or immigration status) ad libitum and refusing any acknowledgment of their complexity. Islamic societies from the maghreb to the mashreq appear monolithic, their cultural mentality being cut from the same transtemporal cloth that allows for neither change nor adaptation. Likewise, at the individual level, the Lebanese student, the refugee from Somalia, and the German-born son of Egyptian immigrants are all regarded as part of the same anti-Occident alliance against which vigorous resistance must be mounted.

Whereas the two master frames give the impression of a threat that is ubiquitous and manifests in different ways, PEGIDA's self-image is clear. Dealing with a "political class" that is viewed as too ignorant to realize what is at stake, too out of touch to really care about it, or even supportive of what must be considered high treason, PEGIDA speakers present themselves as authentic champions of an overwhelmed people (Volk, 2020). This kind of authenticity is also expressed through a sarcastic and brutal language that seeks to ridicule the "Other" and cultivates a community spirit built upon civilizationist notions of belonging. Speaking truth to power is what PEGIDA speakers claim to do - and while their "truths" may be contradictory (e.g., immigrants refuse to integrate versus immigrants are too well integrated), there is an emotional element to them that is of far greater importance than their factual foundation.

Though the case of PEGIDA substantiates the idea that moments of crisis bear significant potential for right-wing populist social movements, there are limitations to our examination that must be acknowledged. First, to keep our data manageable, we analyzed only a limited number of rallies and did not evaluate whether PEGIDA's framing affected the political priorities of its supporters and sympathizers.
Furthermore, we analyzed a constellation characterized by significant issue proximity: As both master frames were tied into the same populist undercurrents, PEGIDA speakers had few problems establishing a discursive continuum between fears of an Islamic takeover and of a refugee invasion. Arguably, other crises may provide less fertile ground in this regard as it is more difficult to frame them as similarly meaningful threats to the mystical Abendland that has successfully survived centuries of plagues and catastrophes.

Moreover, one should be aware that the stimulating impact of the "refugee crisis" was temporary rather than permanent and did not prevent PEGIDA from disintegrating and falling into the abyss of political irrelevance. While its supporters continue to march in Dresden ${ }^{11}$ and have celebrated their $200^{\text {th }}$ Spaziergang as recently as February 2020, their number today is negligible and their discursive power greatly restrained. In retrospect, PEGIDA appears as a red giant in the vastness of Europe's and Germany's right-wing populist galaxy: luminous and stunning at first but bound to collapse and fade from our vision. At least in part, this collapse may be the result of the movement's decentralized nature (which made it difficult to use frames strategically) and its radical language (which scared off many moderate sympathizers). In any case, PEGIDA proved unable to cement the dialogicality of its frames, with even the AfD developing an ambiguous stance toward what was once seen as a natural ally (Korsch, 2016).

Thus, if we were to generalize, a possible inference could be that populist parties enjoy structural advantages over populist social movements. They are (1) more flexible when it comes to adapting their message in the wake of crises, and (2) better equipped to develop long-term strategies to exploit them. But to validate these two assumptions and draw additional insights,

11 Due to the COVID-19 pandemic, PEGIDA's rallies were suspended in early 2020 but later resumed. However, in the face of the pandemic's second wave (from September 2020), the sixth anniversary rally of the movement was cancelled by state authorities. 
more research on populist communication is still required. Such research may include, but is not limited to, comparisons between PEGIDA and other populist social movements, critical discourse analysis to lay bare the determinants of its modus operandi, and detailed explorations of how the two master frames described in this article have developed after 2016.

\section{Acknowledgement}

This work was financially supported by the NCCR - on the move [Grant Number 51NF40-182897].

\section{Conflict of interest}

The authors declare no conflict of interests.

\section{References}

Aalberg, T., \& de Vreese, C. H. (2017). Introduction: Comprehending populist political communication. In T. Aalberg, F. Esser, C. Reinemann, J. Strömbäck, \& C. H. de Vreese (Eds.), Populist political communication in Europe (pp. 3-11). New York, NY: Routledge.

Barr, R. R. (2009). Populists, outsiders and anti-establishment politics. Party Politics, 15(1), 29-48. https://doi. org/10.1177/1354068808097890

Benford, R. D., \& Snow, D. A. (2000). Framing processes and social movements: An overview and assessment. Annual Review of Sociology, 26(1), 611-639. https://doi. org/10.1146/annurev.soc.26.1.611

Bennett, W. L., \& Segerberg, A. (2012). The logic of connective action: Digital media and the personalization of contentious politics. Information, Communication \& Society, 15(5), 739-768. https://doi.org/10.1080/13 69118X.2012.670661

Berntzen, L. E., \& Weisskircher, M. (2016). Anti-Islamic PEGIDA beyond Germany: Explaining differences in mobilisation. Journal of Intercultural Studies, 37(6),
556-573. https://doi.org/10.1080/0725686 8.2016.1235021

Bitschnau, M., Ader, L., Ruedin, D., \& D’Amato, G. (2021). Politicising immigration in times of crisis: Empirical evidence from Switzerland. Journal of Ethnic and Migration Studies, 47(17), 3864-3890. https://doi. org/10.1080/1369183X.2021.1936471

Bock, J.-J. (2019). Negotiating cultural difference in Dresden's Pegida movement and Berlin's refugee church. In J.-J. Bock \& S. Macdonald (Eds.), Refugees welcome? Difference and diversity in a changing Germany (pp. 214-240). New York, NY: Berghahn.

Bogert, L., \& Fielitz, M. (2019). "Do you want meme war?" Understanding the visual memes of the German far right. In M. Fielitz \& N. Thurston (Eds.), Post-digital cultures of the far right: Online actions and offline consequences in Europe and the U.S. (pp. 137-153). Bielefeld, Germany: transcript.

Bonikowski, B., Halikiopoulou, D., Kaufmann, E., \& Rooduijn, M. (2019). Populism and nationalism in a comparative perspective: A scholarly exchange. Nations and Nationalism, 25(1), 58-81. https://doi. org/10.1111/nana. 12480

Boulila, S. C., \& Carri, C. (2017). On Cologne: Gender, migration and unacknowledged racisms in Germany. European Journal of Women's Studies, 24(3), 286-293. https:// doi.org/10.1177\%2F1350506817712447

Brubaker, R. (2017). Between nationalism and civilizationism: The European populist movement in comparative perspective. Ethnic and Racial Studies, 40(8), 11911226. https://doi.org/10.1080/01419870.2 017.1294700

Chryssochoou, X. (2018). 'Betrayed believers': The target of influence of extreme rightwing minorities. International Review of Social Psychology, 31(1), 1-12. https://doi. org/10.5334/irsp.38

Daphi, P., Kocya, P., Neuber, M., Roose, J., Rucht, D., Scholl, F., \& Zajak, S. (2015). Protestforschung am Limit. Eine soziologische Annäherung an PEGIDA [Protest research at its limits: A sociological approach toward PEGIDA]. Berlin, Germany: Initiative für Protest- und Bewegungsforschung. 
della Porta, D. (2012). Mobilizing against the crisis, mobilizing for "another democracy": Comparing two global waves of protest. Interface, 4, 274-277.

della Porta, D. (2015). Social movements in times of austerity: Bringing capitalism back into protest analysis. London, UK: John Wiley \& Sons.

della Porta, D., \& Mattoni, A. (2014). Patterns of diffusion and the transnational dimension of protest in the movements of the crisis: An introduction. In D. della Porta \& A. Mattoni (Eds.), Spreading protest: Social movements in times of crisis (pp. 1-18). Colchester, UK: ECPR Press.

Entman, R. M. (1993). Framing: Toward clarification of a fragmented paradigm. Journal of Communication, 43(4), 51-58. https://doi.org/10.1111/j.1460-2466.1993. tb01304.x

Ernst, N., Engesser, S., Büchel, F., Blassnig, S., \& Esser, F. (2017). Extreme parties and populism: An analysis of Facebook and Twitter across six countries. Information, Communication \& Society, 20(9), 1347-1364. https://doi.org/10.1080/13691 18X.2017.1329333

Ernst, N., Esser, F., Blassnig, S., \& Engesser, S. (2019). Favorable opportunity structures for populist communication: Comparing different types of politicians and issues in social media, television and the press. International Journal of Press/ Politics, 24(2), 165-188. https://doi. org/10.1177/1940161218819430

Gaby, S., \& Caren, N. (2012). Occupy online: How cute old men and Malcolm X recruited 400,000 US users to OWS on Facebook. Social Movements Studies, 11(3-4), 367-374. https://doi.org/10.1080/1474283 7.2012 .708858

Gamson, W. A., \& Meyer, D. S. (1996). Framing political opportunity. In D. McAdam, J. D. McCarthy, \& M. N. Zald (Eds.), Comparative perspectives on social movements: Political opportunities, mobilizing structures, and cultural framing (pp. 275-311). Cambridge, UK: Cambridge University Press.

Gerbaudo, P. (2017). The indignant citizen: Anti-austerity movements in southern Europe and the anti-oligarchic reclaiming of citizenship. Social Movement Studies,
16(1), 36-50. https://doi.org/10.1080/1474 2837.2016.1194749

Gidron, N., \& Bonikowski, B. (2013). Varieties of populism: Literature review and research agenda. Cambridge, MA: Weatherhead Center for International Affairs. https:// dx.doi.org/10.2139/ssrn.2459387

Guenther, L., Ruhrmann, G., Bischoff, J., Penzel, T., \&Weber, A. (2020). Strategic framing and social media engagement: Analyzing memes posted by the German Identitarian Movement on Facebook. Social Media + Society, 6(1), 1-13. https:// doi.org/10.1177/2056305119898777

Haller, A., \& Holt, K. (2019). Paradoxical populism: How PEGIDA relates to mainstream and alternative media. Information, Communication \& Society, 22(12), 1665-1680. https://doi.org/10.1080/13691 18X.2018.1449882

Hatakka, N., Niemi, M. K., \& Välimäki, M. (2017). Confrontational yet submissive: Calculated ambivalence and populist parties' strategies of responding to racism accusations in the media. Discourse \& Society, 28(3), 262-280. https://doi. org/10.1177\%2F0957926516687406

Jagers, J., \& Walgrave, S. (2007). Populism as political communication style: An empirical study of political parties' discourse in Belgium. European Journal of Political Research, 46(3), 319-345. https://doi. org/10.1111/j.1475-6765.2006.00690.x

Jecker, C. (2014). Entmans Framing-Ansatz: Theoretische Grundlegung und empirische Umsetzung [Entman's framing approach: Theoretical foundation and empirical application]. Konstanz, Germany: UVK.

Kalsnes, B. (2019). Examining the populist communication logic: Strategic use of social media in populist parties in Norway and Sweden. Central European Journal of Communication, 12(2), 187-205. https:// doi.org/10.19195/1899-5101.12.2(23).5

Kemper, A. (2015). AfD, PEGIDA and the New Right in Germany. In G. Charalambous (Ed.), The European far right: Historical and contemporary perspectives (pp. 43-48). Report 2/2015. Nicosia, Cyprus: PRIO Cyprus Center \& Friedrich-Ebert-Stiftung.

Koopmans, R., \& Duyvendank, J. W. (1995). The political construction of the nuclear energy issue and its impact in the mobilization 
of anti-nuclear movements in Western

Europe. Social Problems, 42(2), 235-251. https://doi.org/10.2307/3096903

Korsch, F. (2016). "Natürliche Verbündete”? Die Pegida-Debatte in der AfD zwischen Anziehung und Ablehnung ["Natural allies"? The AfD's Pegida debate between attraction and rejection]. In A. Häusler (Ed.), Die Alternative für Deutschland: Programmatik, Entwicklung und politische Verortung (pp. 111-134). Wiesbaden, Germany: Springer VS.

Kriesi, H. (2014). The populist challenge. West European Politics, 37(2), 361-378. https:// doi.org/10.1080/01402382.2014.887879

Langman, L. (2013). Occupy: A new new social movement. Current Sociology, 61(4), 510-524. https://doi.org/ $10.1177 \% 2 F 0011392113479749$

Lichtenstein, D. (2021). No government mouthpieces: Changes in the framing of the "migration crisis" in German news and infotainment media. Studies in Communication Science (SComS), 21(2), 267-284. https://doi.org/10.24434/j. scoms.2021.02.005

Lichtenstein, D., Ritter, J., \& Fähnrich, B. (2017). The migrant crisis in the German public discourse. In M. Barlai, B. Fähnrich, C. Griessler, \& M. Rhomberg (Eds.), The migrant crisis: European perspectives and national discourses (pp. 107-127). Münster, Germany: LIT.

Maly, I. (2019). New right metapolitics and the algorithmic activism of Schild \& Vrienden. Social Media + Society, 5(2), 1-15. https:// doi.org/10.1177/2056305119856700

Mayring, P. (2014). Qualitative content analysis. Theoretical foundation, basic procedures and software solution. Klagenfurt, Austria: Beltz.

Mazzoleni, G. (2014). Mediatization and political populism. In F. Esser \& J. Strömbäck (Eds.), Mediatization of politics. Understanding the transformation of Western democracies (pp. 42-56). Basingstoke, UK: Palgrave Macmillan.

Mazzoleni, G., Stewart, J., \& Horsfield, B. (2003). The media and neo-populism: A contemporary comparative analysis. Westport, CT: Praeger.

McAdam, D., McCarthy, J. D., \& Zald, M. N. (1996). Introduction: Opportunities, mobilizing structures, and framing processes - Toward a synthetic comparative perspective on social movement. In D. McAdam, J. D. McCarthy, \& M. N. Zald (Eds.), Comparative perspectives on social movements: Political opportunities, mobilizing structures, and cultural framing (pp. 1-20). Cambridge, UK: Cambridge University Press.

Moffitt, B. (2016). The global rise of populism: Performance, political style, and representation. Stanford, CA: Stanford University Press.

Mudde, C. (2004). The populist zeitgeist. Government and Opposition: An International Journal of Comparative Politics, 39(4), 541-563. https://doi.org/10.1111/j.14777053.2004.00135.x

Mudde, C. (2007). Populist radical right parties in Europe. Cambridge, UK: Cambridge University Press.

Mudde, C., \& Rovira Kaltwasser, C. (2012). Populism in Europe and the Americas: Threat or corrective for democracy? Cambridge, UK: Cambridge University Press.

Nissen, A. (2020). The trans-European mobilization of "Generation Identity". In O. C. Norocel, A. Hellström, \& M. B. Jørgensen (Eds.), Nostalgia and hope: Intersections between politics of culture, welfare, and migration in Europe (pp. 85-100). Cham, Switzerland: Springer.

Norris, P., \& Inglehart, R. (2019). Cultural backlash: Trump, Brexit, and authoritarian populism. Cambridge, UK: Cambridge University Press.

Patzelt, W., \& Klose, J. (2016). PEGIDA. Warnsignale aus Dresden [PEGIDA. Warning signals from Dresden]. Dresden, Germany: Thelem.

Puschmann, C., Ausserhofer, J., \& Šlerka, J. (2020). Converging on a nativist core? Comparing issues on the Facebook pages for the Pegida movement and the Alternative for Germany. European Journal of Communication, 35(3), 230-248. https:// doi.org/10.1177/0267323120922068

Priante, A., Ehrenhard, M. L., van den Broek, T., \& Need, A. (2018). Identity and collective action via computer-mediated communication: A review and agenda for future research. New Media \& So- 
ciety, 20(7), 2647-2669. https://doi. org/10.1177/1461444817744783

Rehberg, K.-S., Kunz, F., \& Schlinzig, T. (Eds.) (2016). PEGIDA-Rechtspopulismus zwischen Fremdenangst und "Wende"-Enttäuschung [PEGIDA - Rightwing populism between xenophobia and disillusionment with the "Wende"]? Bielefeld, Germany: transcript.

Rooduijn, M. (2014). The mesmerising message: The diffusion of populism in public debates in Western European media. Political Studies, 62(4), 726-744. https://doi. org/10.1111\%2F1467-9248.12074

Rooyackers, I., \& Verkuyten, M. (2012). Mobilizing support for the extreme right: A discursive analysis of minority leadership. British Journal of Social Psychology, 51(1), 130-148. https://doi.org/10.1111/ j.2044-8309.2010.02008.x

Rosenthal, U., t'Hart, P., \& Charles, M. T. (1989). The world of crises and crisis management. In U. Rosenthal, M. T. Charles, \& P. t'Hart (Eds.), Coping with crises: The management of disasters, riots and terrorism (pp. 3-33). Springfield, IL: Charles C. Thomas.

Rucht, D., \& Neidhardt, F. (2001). Soziale Bewegungen und kollektive Aktionen [Social movements and collective actions]. In H. Joas (Ed.), Lehrbuch der Soziologie (pp. 533-556). Frankfurt am Main, Germany: Campus.

Seeger, M. W., \& Sellnow, T. L. (2016). Narratives of crisis: Telling stories of ruin and renewal. Stanford, CA: Stanford University Press.

Snow, D. A., Vliegenthart, R., \& Ketelaars, P. (2019). The framing perspective on social movements: Its conceptual roots and architecture. In D. A. Snow, S. A. Soule,
H. Kriesi, \& H. J. McCammon (Eds.), The Blackwell companion to social movements (pp. 392-410). Hoboken, NJ: John Wiley \& Sons.

Stanley, B. (2008). The thin ideology of populism. Journal of Political Ideologies, 13(1), 95-110. https://doi. org/10.1080/13569310701822289

Stier, S., Posch, L., Bleier, A., \& Strohmaier, M. (2017). When populists become popular: Comparing Facebook use by the rightwing movement Pegida and German political parties. Information, Communication \& Society, 20(9), 1365-1388. https://doi.org /10.1080/1369118X.2017.1328519

Volk, S. (2020). "Wir sind das Volk!” Representative claims-making and populist style in the PEGIDA movement's discourse. German Politics, 29(4), 599-616. https:// doi.org/10.1080/09644008.2020.1742325

Vorländer, H., Herold, M., \& Schäller, S. (2018). PEGIDA and new right-wing populism in Germany. Cham, Switzerland: Palgrave Macmillan.

Walby, S. (2015). Crisis. Cambridge, UK: Polity Press.

Weber, B. (2016). "We must talk about Cologne": Race, gender, and reconfigurations of "Europe". German Politics and Society, 34(4), 68-86. https://doi.org/10.3167/ gps.2016.340405

Weyland, K. (2001). Clarifying a contested concept: Populism in the study of Latin American politics. Comparative Politics, 34(1), 1-22. https://doi.org/10.2307/422412

Wodak, R., KhosraviNik, M., \& Mral, B. (Eds.) (2013). Right-wing populism in Europe: Politics and discourse. London, UK: Bloomsbury. 